Sakowicz wskazywał, na podstawie metody analizy personalistycznej, na „ojcostwo” Jana Pawła II wobec religii świata. W sesji szóstej refleksji poddano kwestię: Osoba jako punkt wyjścia personalistycznej edukacji i pedagogiki. Pierwsza referentka Pani prof. KUL, dr hab. Alina Rynio, zwróciła uwagę na ontologiczny wymiar człowieka jako podstawę integralnego wychowania osoby w nauczaniu Karola Wojtyły/ Jana Pawła II. Wieńcząc całe spotkanie, ks. prof. dr hab. Marian Nowak przedstawił „introspekcję osoby z pozycji pedagogiki personalistycznej”. Wszystkim sesjom warsztatowym towarzyszyły żywe dyskusje prelegentów i ich słuchaczy.

Na zakończenie sesji przeprowadzono dyskusję, po której dokonano podsumowania obrad, przedstawiono tematy i plany pracy Zespołu na rok 2020/21.

\author{
ALINA RYNIO \\ Instytut Pedagogiki KUL \\ e-mail:memor@kul.pl \\ ORCID: https://orcid.org/0000-0003-4113-7620 \\ DOI: https://doi.org/10.18290/rped21131.13
}

\title{
SPRAWOZDANIE Z POSIEDZENIA SEKCJI \\ PEDAGOGIKI CHRZEŚCIJAŃSKIEJ \\ KOMITETU NAUK PEDAGOGICZNYCH POLSKIEJ AKADEMII NAUK
}

W dniu 21 października 2020 r., zgodnie z przyjętym uprzednio harmonogramem, pomimo panującej pandemii odbyło się kolejne posiedzenie Sekcji Pedagogiki Chrześcijańskiej działającej pod Patronatem KNP PAN. Było ono możliwe dzięki wykorzystaniu platformy uniwersyteckiej i rozwiązaniom technicznym za pośrednictwem aplikacji MS TEAMS.

Tradycyjnie o godz. 9.00 odprawiona została Msza św., celebrowana przez ks. prof. Mariana Nowaka w intencji wszystkich członków SPCH. Tym razem ci, którzy chcieli w niej uczestniczyć, łączyli się on-line z Kaplicą na ul. Bernardyńskiej 7 w Lublinie.

O godz. 10.00 rozpoczęło się posiedzenie Sekcji Pedagogiki Chrześcijańskiej poświęcone jakże ważnej kwestii, jaką jest: Nowy humanizm św. Jana Pawła II i jego znaczenie dla wspótczesnej pedagogiki. Do analizowania tej problematyki (przeniesionej ze względu na pandemię z maja 2020 r.) wprowadzali uprzednio zgłoszeni prelegenci reprezentujący różne środowiska akademickie w Polsce. W trakcie posie- 
dzenia, w pierwszej jego części, po uroczystym powitaniu licznego grona członków Sekcji i gości (warto odnotować, że łącznie uczestniczyły 72 osoby) Przewodniczący SPCH, ks. prof. Marian Nowak, dokonał stosownego wprowadzenia i oddał głos ks. prof. UKSW, dr. hab. Stanisławowi Chrobakowi - dziekanowi Wydziału Pedagogicznego UKSW. Przedstawił on bardzo aktualny i ważny temat poświęcony odpowiedzialności człowieka nauki. Swoje cenne refleksje prelegent ukazał „W świetle nauczania Jana Pawła II".

Jako druga swój referat zaprezentowała, pisząca te słowa, Alina Rynio z Instytutu Pedagogiki KUL (Lublin). Mając na uwadze temat przewodni posiedzenia SPCH swoje wystąpienie prelegentka skoncentrowała na Nowości i znaczeniu nauczania Jana Pawła II o wychowaniu. Mając za sobą wcześniejsze badania w zakresie integralnego wychowania w myśli Jana Pawła II, które prelegentka prezentowała na spotkaniu wrześniowym w Kazimierzu, gdzie starała się przybliżyć ontyczny wymiar człowieka jako podstawe integralnego wychowania osoby, w swoim referacie z 21 października 2020 r. przedłożyła zaledwie kilka argumentów potwierdzających nowość $i$ znaczenie papieskiego nauczania o wychowaniu ${ }^{1}$. W pierwszej części swojego wystąpienia referująca przywołała papieskie sposoby rozumienia istoty wychowania ujmowanego w aspekcie jego integralności, nowości i wzajemnego obdarzania się człowieczeństwem. W części drugiej wskazała na teologiczno-antropologiczne źródła owej nowości. Następnie, mając na względzie znaczenie omawianej myśli pedagogicznej, przywołała argumenty przemawiające za metodyczną wartością analizowanego nauczania. Na koniec prelegentka zasygnalizowała nadzieje związane z owym przesłaniem dla współcześnie wychowujących. W konkluzji stwierdziła, iż „,zaprezentowane źródła i przejawy ponadczasowej aktualności papieskiej wizji wychowania odsłaniają jej integralne ujęcie. Widać je przede wszystkim w przyjmowanej przezeń i przenikniętej wiarą antropologicznej refleksji nad człowiekiem. W refleksji tej integralne widzenie człowieka warunkuje integralne wychowanie osoby”.

Dokonane analizy potwierdzają tezę, że papieska pedagogia zakłada ,adekwatną antropologię" i otwarcie ludzkiego serca na prawdę w porządku obiektywnym, w tym prawdę o Chrystusie, który jest „centrum wszechświata i historii” (RH 1) oraz fundamentem prawdy o człowieku. Zdaniem prelegentki „Papieska pedagogia, mając swoje podstawy antropologiczne, jest aktualna i atrakcyjna, gdyż pozwala na miarę współczesnych czasów wypracować całościową wizję wychowania człowieka. Wizja ta przeciwstawia się kulturze zwątpienia, dehumanizacji, nihilizmu i egzystencjalnego cynizmu, a także aksjologicznego relatywizmu. W wizji tej nauka, technika i sztuka, pokój i sprawiedliwość, poznanie Boga i prawdziwa religia, natura i łaska, wiara, nadzieja i miłość nie wykluczają się wzajemnie, ale się dopełniają".

Ponadto „ponadczasowe źródło aktualności papieskiego przesłania pedagogicznego zdaje się tkwić w tym, że bazując na kompatybilności i kompletności obrazu

\footnotetext{
${ }^{1}$ Por. A. RYNIO (2004). Integralne wychowanie w myśli Jana Pawła II. Lublin: Wydawnictwo KUL.
} 
człowieka pozwala ono przemyśleć złożoną kwestię wychowania i osobniczą historię kształtowania się osobowości ludzi nieprzeciętnych”. Zdaniem prelegentki „pozwala też z szacunkiem i zdumieniem pochylić się nad katolicką interpretacją wychowania i ludzkiego losu".

W dalszej kolejności głos zabrał prof. UŚ, dr hab. Marek Rembierz, reprezentujący Wydział Etnologii i Nauk o Edukacji UŚ w Cieszynie. W swoim wystąpieniu przedłożył Polskie doświadczenie wielokulturowości w interpretacji Jana Pawła II jako inspiracja dla edukacji międzykulturowej. Głównym założeniem referującego było, że interpretacja polskich doświadczeń w zakresie wielokulturowości - w rozumieniu Jana Pawła II - może stać się inspiracją dla edukacji międzykulturowej i pedagogiki porównawczej religii. Zdaniem prelegenta może się to zdarzyć głównie dlatego, że kwestia kultury i wychowania $\mathrm{w}$ aspekcie partykularności i uniwersalności, która jest rozważana w badaniach nad edukacją międzykulturową, jest obecna w interpretacji polskich doświadczeń wielokulturowości realizowanej przez Jana Pawła II. Połączył on polskie doświadczenie wielokulturowości z własnym, osobistym doświadczeniem, które ukształtowały jego tożsamość, a także doświadczenie moralne i doświadczanie wiary chrześcijańskiej. Zdaniem prelegenta dla tych, którzy mają wspólne aksjologiczne przekonania promowane przez Jana Pawła II, papieska interpretacja polskiego doświadczenia wielokulturowości może mieć znaczenie kluczowe. Widzą oni istotne zalety papieskiej interpretacji kultury jako takiej i polskiego etosu. Jeżeli interpretacja ta zostanie uznana za słuszną, nabywa cechy intelektualnie i moralnie ważnego punktu odniesienia dla aksjologicznego i edukacyjnego znaczenia polskiego doświadczenia wielokulturowości. Prelegent, powołując się na papieskie źródła, a w szczególności na autobiobraficzną książkę Jana Pawła II Pamięć i tożsamość. Rozmowy na przełomie tysiącleci, zwrócił też uwagę, że „Polskość to w rzeczywistości wielość i pluralizm, a nie zwężenie i uwięzienie”. Zastrzegł jednak, że ten „jagielloński” wymiar polskości [...] przestał być niestety, czymś oczywistym w naszych czasach". Zdaniem prelegenta wartości, jakimi są wielość i otwartość, trzeba umieć przyswoić sobie we własnym doświadczeniu egzystencjalnym i moralnym. „Uznanie, że o właściwie rozumianej polskości stanowią „wielość i pluralizm”, a nie „ciasnota i zamknięcie”, określa aksjologiczne zasady kształtowania przekonań i postaw w relacjach międzyludzkich w złożonej sytuacji wielokulturowości”. Oprócz charakterystyki polskiego doświadczenia, jako przypadku uniwersalnego dramatu człowieczeństwa, w finalnej części swego referatu prelegent zwrócił uwagę na Jana Pawła II inspiracje płynące dla edukacji międzykulturowej i kształtowania tożsamości pogranicza.

Następnie głos zabrał prof. dr hab. Andrzej Jakub Sowiński z Akademii im. Jakuba z Paradyża (Gorzów Wielkopolski), wygłaszając referat pt Funkcja krytyczna pedagogiki jako nauki humanistycznej.

Jako ostatni wystąpił ks. prof. dr hab. Marian Nowak (Instytut Pedagogiki KUL, Lublin), prezentując niezwykle ważny i interesujący temat, który zatytułował: 
Ku spotkaniu nowego humanizmu z etyka, pedagogika i teologia $w$ nauczaniu Jana Pawta II. Po zoperacjonalizowaniu podstawowych kwestii zawartych w temacie, prelegent zwrócił uwagę na ponadczasowy walor Nowej ewangelizacji lansowanej przez Jana Pawła II i znaczenie jego nauczania dla pedagogiki.

Po wystąpieniach referatowych miała miejsce ożywiona dyskusja uczestników spotkania zogniskowana wokół treści wystąpień poszczególnych prelegentów. Całość spotkania, które odbyło się w bardzo przyjaznej atmosferze, dopełniły informacje i sprawy organizacyjne dotyczące pracy Sekcji Pedagogiki Chrześcijańskiej na rok $2020 / 21$ 